\title{
Craniofacial Morphometric Study of Annang Tribe in Akwa Ibom State, Nigeria
}

\author{
Kingsley A. Okon*, Eno-obong I. Bassey, Gabriel D. Edem, Iboro E. Edet \& Okesina, B. Ayoola \\ Department of Anatomy, College of Health Sciences, University of Uyo, Nigeria. \\ DOI: http://doi.org/10.38177/AJBSR.2021.3203 \\ Copyright: @2021 Kingsley A. Okon et al. This is an open access article distributed under the terms of the Creative Commons Attribution License, which \\ permits unrestricted use, distribution, and reproduction in any medium, provided the original author and source are credited.
}

\section{ABSTRACT}

Craniofacial morphometric study is an anthropometric technique used in the evaluation of several systemic syndromes, craniofacial abnormalities and in the surgical treatment of post traumatic telecanthus. This study was aimed at determining standard values for head circumference, inner canthal distance, outer canthal distance, canthal index and circumference interorbital index of adult Annangs between the ages of 18-47. The study was conducted in University of Uyo, Akwa Ibom State Polytechnic, Ikot Osurua, Essien Udim, Abak and Ikot Ekpene Local Government Areas all in Akwa Ibom State. A total of 900 (450 males and 450 females) of Annang adults between the ages of $18-47$ were selected for this study. The ages were grouped as follows: 18-27 (300 subjects, 33.3\%), 28-37 (300 subjects, 33.3\%) and 38-47 (300 subjects, 33.3\%). Morphological measurements of head conference $(H C)$, inner canthal distance (ICD) and outer canthal distance $(O C D)$ were measured using standard anthropometric methods. Canthal index (CI) and circumference interorbital index (CI.I) were calculated as ICD/OCDX100 and ICD/HCx100 respectively. The mean values for male subjects( $32.2 \pm 8.8$ years) were found to be $56.5 \pm 1.5 \mathrm{~cm}$ for head circumference, $4.1 \pm 0.4 \mathrm{~cm}$ for intercanthal distance, $12.7 \pm 0.6 \mathrm{~cm}$ for outer canthal distance, $29.3 \pm 2.5 \mathrm{~cm}$ for canthal index and $6.8 \pm 4.1 \mathrm{~cm}$ for circumference interorbital index. Statistical analysis showed that males had significantly higher values than the females in all the parameters measured $(p<0.05)$ except head circumference where the females had a slightly higher value showing some form of sexual dimorphism. The knowledge of these values are important because normal values of head circumferences inner and outer canthal distances, canthal index and circumference interorbital index are useful parameters in the evaluation and treatment of congenital and or post traumatic deformities of the cephalic and facial regions such as telecanthus, ocular hypotelorism and craniosynostosis.

Keywords: Head circumference, Inner and outer canthal distances, Canthal index, Annang.

\section{Introduction}

The Annang people of Nigeria consist of over one million people in the Western part of Akwa-Ibom State of Nigeria. The Annangs are indigenous to Abak, Ikot-Ekpene, Ika, Etim-Ekpo, Essien-Udim, Obot-Akara, Oruk-Anam and Ukanafun Local Government Areas of the state (Udo, 1983). They share a common boundary with the Igbos to the North-West and South-West, the Ibibios to the North-East, East and South-East. They speak the Annang language with its various dialects as their general language (Umoh, 2004). The Annang people are predominantly farmers, Artisans and traders. Their craftsmanship in raffia and wood carving is well known. Culturally, the Annangs engage in masquerade celebrations that include Akata, Ekong, Asian Akan, Anwan and Ekpo masquerade celebrations. The Annangs also have many cultural groups of which Uko Akpan and Nka Ikemesit are the most prominent (Ekanem, 2002). Craniofacial morphometric study which includes head circumference also known as fronto-occipital circumference, intercanthal distance, canthal index and circumference interorbital index is an anthropometric technique used in the evaluation of several systemic syndromes, craniofacial abnormalities and in the surgical treatment of post traumatic telecanthus (Farkes et al., 1992a, 1992b). Canthal index and circumference interorbital index which are derived from the measurements are also important to craniofacial surgeons and anatomists (Anibor et al., 2014).

However, facial proportion changes with age and sex in a given race as a result of variation in the skeletal dimension, muscle development and are dependent on environmental factors such as diet, health and climatic influences which are important determinants of growth and development (Francis, 2000). Knowledge of the normal value for a particular region will be used to treat abnormalities to produce the best aesthetic and functional results 
(Evereklioglu et al., 2002). The evaluation and measurement of the human body dimensions is achieved by physical anthropometry (Williams et al., 1995).

Circumference inter-orbital index of African Americans has been studied, reports show that male and female of this population have mean values of 5.89 and 6.02 respectively (Juberg et al., 1975). The data and comprehensive documentation will enable the forensic scientists to identify the adult Annangs.

\section{Materials and methods}

\subsection{Research design}

Anthropometrical measurements of the craniofacial morphometrics which include head circumference, intercanthal distances (outer and inner canthal distances), canthal index and circumference inter-orbital index of adult Annangs of Akwa Ibom State of Nigeria were undertaken.

A total of nine hundred (900) subjects including four hundred and fifty (450) males and four hundred and fifty (450) females were selected from the different Local Government Areas that make up the Annang Tribe of Akwa Ibom State and measured for this study.

\subsection{Population of study}

Individuals from the Annang tribe of Akwa Ibom State of Nigeria from eighteen (18) years and above grouped under the age brackets of 18-27, 28 -37 and 38-47 were measured using anthropometric technique.

\subsection{Sampling technique and sample size}

Random sampling technique was used for data collection for the respective subjects. Informed consent was taken from the participants. The participants were initially oriented for the purpose of the study and assured that anonymity would be maintained. The sample size was nine hundred (900) subjects including four hundred and fifty (450) males and four hundred and fifty females (450). Minimum sample size expected of the study was exceeded.

\subsection{Inclusion criteria}

The following were the inclusion criteria for this study;

- Subjects were selected based on their origin from any of the Local Government Areas that make up the Annang tribe.

- All subjects were Annangs by both parents and genealogies.

- They include male and female subjects of eighteen (18) years and above.

- They all had normal craniofacial configuration.

\subsection{Exclusion criteria}

The following were the exclusion criteria for this study;

- Individuals below eighteen (18) years and not of Annang origin were excluded from this study.

- Individuals that have done plastic surgery or have any craniofacial anomaly were also excluded. 


\subsection{Data collection instruments}

The following materials were used for the measurements of the head circumference and inter-canthal distances while the canthal index and circumference inter-orbital index were derived from them; Non- stretchable transparent plastic meter rule, tailor tape, methylated spirit cotton wool, plastic chair and disposable hand gloves.

\subsection{Data collection methods}

\subsubsection{Measurement of head circumference}

The head circumference was determined by placing the tape rule from the occipital prominence to the supra orbital bridge using the method described by Oladipo et al., (2013). Each subject was seated comfortably in a chair with the subject's head at the same level as the head of the examiner. In the case of fashionable hairstyles especially for the females, the tape was drawn tightly and compressed against the hair as much as possible. In the cases of braided female subjects, the tape was allowed to come in contact with the skin and over the lump of the hair.

\subsubsection{Measurement of inner canthal distance}

The inner canthal distance was determined by having the subject look straight in an anatomical position at the examiner while the non- stretchable transparent centimetre ruler was held tightly against the bridge of the nose from the left medial angle to the right medial angle of the palpebral fissures.

\subsubsection{Measurement of outer canthal distance}

The outer canthal distance was determined by having the subject look straight in an anatomical position at the examiner while the non- stretchable transparent centimetre ruler was held from the left lateral angle to the right lateral angle of the palpebral fissures.

\subsubsection{Determination of canthal index}

The canthal index(CI) was derived from the inner and outer canthal distances by dividing the inner canthal distance(ICD) by the outer canthal distance(OCD) and multiplying it by one hundred. Mathematically,

Canthal Index $(\mathrm{CI})=\frac{\text { Inner Canthal Distance (ICD) }}{\text { Outer Canthal Distance (OCD) }} \times 100$

(Oladipo et al., 2011, Jaja et al., 2011).

\subsubsection{Determination of circumference inter-orbital index}

The circumference inter - orbital index (CI.I) was derived by dividing the inner canthal distance by the head circumference and multiplying by one hundred. Mathematically,

Circumference inter-orbital index (CI.I) $=\frac{\text { Inner Canthal Distance (ICD) }}{\text { Head Circumference (HC) }} \times 100 \quad$ Osunwoke et al., 2012, Oladipo et al., 2013).

\subsection{Statistical analysis}

Data obtained from the study was subjected to statistical analysis using SPSS version 23 . The mean \pm standard deviation and Pearson Correlation was determined for the various parameters. 
3. Results

Craniofacial Morphometric study which involves head circumference, inter canthal distances (inner and outer canthal distances), canthal index and circumference interorbital index among the adult Annangs of Akwa Ibom State were studied using a sample size of nine hundred (900) subjects including 450 males and 450 females. The result of this study is presented in the tables below. The subjects were divided into three age groups: 18-27, 28-37 and 38-47 respectively. Table 1 shows the mean \pm SD for head circumference (HC), inner canthal distance (ICD), outer canthal distance (OCD), canthal index (CI) and circumference interorbital index (CI.I) of Annang males and females. The overall result for both Annang male and female is presented in Table 2. Results from Table 2 shows that the mean and standard deviation of the head circumference of Annang males and females were $56.5 \pm 1.5$ and $56.8 \pm 1.9(\mathrm{~cm})$ respectively. This shows that the Annang females had a slightly higher head circumference than the Annang males. The mean and standard deviation of inner canthal distance and outer canthal distance of Annang males and females were $4.1 \pm 0.4,13.1 \pm 0.5(\mathrm{~cm})$ and $3.7 \pm 0.4,12.7 \pm 0.6(\mathrm{~cm})$ respectively. This shows that the Annang males had a significantly higher ICD and OCD than the females. The mean and standard deviation of canthal index and circumference interorbital index for Annang males was 31.6 \pm 2.8 and $7.3 \pm 0.7$ while for females it was $29.3 \pm 2.5$ and $6.8 \pm 4.1$. This shows that the Annang males also had a significantly higher CI and CI.I than the females. It was observed in all the parameters that the males had a significantly higher value than the females except in head circumference where the females had a higher value. Table 3 shows a comparison of the mean \pm SD values of the various parameters of the present and previous studies. It was observed that there were ethnic differences in the parameters. Figures 1 and 2 shows the Pearson correlation between canthal index and circumference interorbital index of both males and females of Annang ethnic group.

Table 1. Table showing the mean+SD of the measured parameters in the different age groups

\begin{tabular}{|c|c|c|c|c|c|c|}
\hline \multirow{2}{*}{$\begin{array}{c}\text { Age Group } \\
\text { MALES }\end{array}$} & \multirow{2}{*}{$\begin{array}{l}\text { Total } \\
\text { Count }\end{array}$} & HC (cm) & ICD $(\mathrm{cm})$ & OCD $(\mathbf{c m})$ & C.I (cm) & C.I.I $(\mathrm{cm})$ \\
\hline & & Mean \pm SD & Mean \pm SD & $\operatorname{Mean} \pm$ SD & $\operatorname{Mean}_{ \pm} \mathbf{S D}$ & Mean \pm SD \\
\hline $18-27$ & 150 & $55.9 \pm 1.6$ & $4.3 \pm 0.4$ & $13.1 \pm 0.6$ & $33.2 \pm 2.8$ & $7.8 \pm 0.7$ \\
\hline $28-37$ & 150 & $56.8 \pm 1.4$ & $4.1 \pm 0.4$ & $13.2 \pm 0.5$ & $31.6 \pm 2.5$ & $7.3 \pm 0.6$ \\
\hline $38-47$ & 150 & $56.7 \pm 1.5$ & $3.9 \pm 0.3$ & $13.0 \pm 0.5$ & $30.1 \pm 2.0$ & $6.9 \pm 0.5$ \\
\hline \multicolumn{7}{|l|}{ FEMALES } \\
\hline $18-27$ & 150 & $56.3 \pm 1.8$ & $3.8 \pm 0.4$ & $12.8 \pm 0.6$ & $29.7 \pm 2.6$ & $6.8 \pm 0.7$ \\
\hline $28-37$ & 150 & $57.0 \pm 1.8$ & $3.7 \pm 0.4$ & $12.7 \pm 0.5$ & $29.3 \pm 2.4$ & $6.5 \pm 0.6$ \\
\hline $38-47$ & 150 & $57.0 \pm 2.0$ & $3.7 \pm 0.5$ & $12.7 \pm 0.7$ & $29.0 \pm 2.4$ & $6.4 \pm 0.7$ \\
\hline
\end{tabular}


Table 2. Table showing overall mean and standard deviation for all parameters

\begin{tabular}{|c|c|c|c|c|}
\hline Variables & Total Count & Mean \pm SD & Minimum & Maximum \\
\hline Males & & & & \\
HC (cm) & 450 & $56.5 \pm 1.5$ & 52.0 & 60.0 \\
ICD (cm) & 450 & $4.1 \pm 0.4^{*}$ & 3.0 & 5.5 \\
OCD (cm) & 450 & $13.1 \pm 0.5^{*}$ & 11.5 & 14.6 \\
CI (cm) & 450 & $31.6 \pm 2.8^{*}$ & 25.8 & 41.6 \\
CI.I (cm) & 450 & $7.3 \pm 0.7^{*}$ & 5.4 & 9.9 \\
\hline Females & 450 & $56.8 \pm 1.9^{*}$ & 52.2 & 62.5 \\
HC (cm) & 450 & $3.7 \pm 0.4$ & 3.0 & 5.3 \\
ICD (cm) & 450 & $12.7 \pm 0.6$ & 11.2 & 14.5 \\
OCD (cm) & 450 & $29.3 \pm 2.5$ & 24.0 & 37.5 \\
C.I (cm) & $6.8 \pm 4.1$ & 5.1 & 9.4 \\
CI.I (cm) & 450 & & & \\
\hline
\end{tabular}

$*=$ significant difference $(p<0.05)$

Table 3. Table showing a comparison of craniofacial morphometrics of present study and previous studies

\begin{tabular}{|c|c|c|c|c|c|c|c|c|c|c|c|}
\hline \multirow{2}{*}{ Researchers } & \multirow{2}{*}{$\begin{array}{l}\text { Ethnic } \\
\text { Group }\end{array}$} & \multicolumn{2}{|c|}{ HC } & \multicolumn{2}{|c|}{ ICD } & \multicolumn{2}{|c|}{ OCD } & \multicolumn{2}{|c|}{ C.I } & \multicolumn{2}{|c|}{ C.I.I } \\
\hline & & $\mathbf{M}$ & $\mathbf{F}$ & $\mathbf{M}$ & $\mathbf{F}$ & $\mathbf{M}$ & $\mathbf{F}$ & $\mathbf{M}$ & $\mathbf{F}$ & $\mathbf{M}$ & $\mathbf{F}$ \\
\hline $\begin{array}{l}\text { Osunwoke } \text { et al., } \\
2012\end{array}$ & Ijaw & $\begin{array}{l}54.4 \pm \\
2.1\end{array}$ & $\begin{array}{l}54.2 \pm \\
2.0\end{array}$ & $\begin{array}{l}2.8 \pm \\
2.1\end{array}$ & $\begin{array}{l}2.8 \pm \\
2.7\end{array}$ & $\begin{array}{l}9.2 \pm \\
3.1\end{array}$ & $\begin{array}{l}9.1 \pm \\
2.6\end{array}$ & $\begin{array}{l}30.0 \pm \\
1.9\end{array}$ & $\begin{array}{l}30.5 \pm \\
1.1\end{array}$ & & \\
\hline Anibor et al., 2014 & Isoko & & & $\begin{array}{l}3.6 \pm \\
1.9\end{array}$ & $\begin{array}{l}3.4 \pm \\
1.2\end{array}$ & $\begin{array}{l}10.6 \pm \\
3.7\end{array}$ & $\begin{array}{l}10.7 \underline{ \pm} \\
0.6\end{array}$ & $\begin{array}{l}35.5 \pm \\
0.9\end{array}$ & $\begin{array}{l}34.6 \pm \\
0.8\end{array}$ & & \\
\hline $\begin{array}{l}\text { Oladipo et al., } \\
2010\end{array}$ & Ibibio & & & $\begin{array}{l}3.5 \pm \\
0.2\end{array}$ & $\begin{array}{l}3.3 \pm \\
0.3\end{array}$ & $\begin{array}{l}11.1 \pm \\
0.5\end{array}$ & $\begin{array}{l}10.7 \underline{ \pm} \\
0.6\end{array}$ & $\begin{array}{l}31.6 \pm \\
2.5\end{array}$ & $\begin{array}{l}31.4 \pm \\
4.6\end{array}$ & & \\
\hline
\end{tabular}




\begin{tabular}{|c|c|c|c|c|c|c|c|c|c|c|c|}
\hline $\begin{array}{l}\text { Oladipo et al., } \\
2013\end{array}$ & Ikwerre & $\begin{array}{l}52.4 \pm \\
2.2\end{array}$ & $\begin{array}{l}51.9 \pm \\
2.1\end{array}$ & $\begin{array}{l}3.3 \pm \\
0.3\end{array}$ & $\begin{array}{l}3.3 \pm \\
0.3\end{array}$ & $\begin{array}{l}9.1 \pm \\
0.6\end{array}$ & $\begin{array}{l}9.3 \pm \\
0.7\end{array}$ & $\begin{array}{l}37.0 \pm \\
2.4\end{array}$ & $\begin{array}{l}36.4 \pm \\
3.1\end{array}$ & $\begin{array}{l}6.8 \pm \\
0.4\end{array}$ & $\begin{array}{l}6.5 \pm \\
0.5\end{array}$ \\
\hline Shah et al., 2014 & Nepal & $\begin{array}{l}56.3+ \\
1.8\end{array}$ & $\begin{array}{l}57.1+ \\
2.1\end{array}$ & $\begin{array}{l}2.4 \pm \\
0.5\end{array}$ & $\begin{array}{l}2.5 \pm \\
0.2\end{array}$ & $\begin{array}{l}10.4 \pm \\
0.5\end{array}$ & $\begin{array}{l}9.5 \pm \\
1.1\end{array}$ & $\begin{array}{l}23.9 \pm \\
5.7\end{array}$ & $\begin{array}{l}27.6 \pm \\
1.2\end{array}$ & $\begin{array}{l}7.9 \pm \\
1.2\end{array}$ & $\begin{array}{l}6.9 \pm \\
2.1\end{array}$ \\
\hline $\begin{array}{l}\text { Oladipo et al., } \\
2008\end{array}$ & Ijaw & & & & & & & & & $\begin{array}{l}7.8 \pm \\
2.2\end{array}$ & $\begin{array}{l}8.1 \pm \\
0.6\end{array}$ \\
\hline Present study & Annang & $\begin{array}{l}56.5 \pm \\
1.5\end{array}$ & $\begin{array}{l}56.8 \pm \\
1.9^{*}\end{array}$ & $\begin{array}{l}4.1 \pm \\
0.4^{*}\end{array}$ & $\begin{array}{l}3.7 \pm \\
0.4\end{array}$ & $\begin{array}{l}13.1 \pm \\
0.5^{*}\end{array}$ & $\begin{array}{l}12.7 \pm \\
0.6\end{array}$ & $\begin{array}{l}31.6 \pm \\
2.8^{*}\end{array}$ & $\begin{array}{l}29.3 \pm \\
2.5\end{array}$ & $\begin{array}{l}7.3 \pm \\
0.7^{*}\end{array}$ & $\begin{array}{l}6.8 \pm \\
4.1\end{array}$ \\
\hline
\end{tabular}

\section{Discussions}

Craniofacial morphometry is important in the evaluation of facial trauma, facial defects, congenital and post traumatic deformities, easy identification of certain congenital malformations and diagnosis of hypo/hypertelorism, macrocephaly etc. Comparative analysis of craniofacial parameters which include head circumference, intercanthal distances, canthal index and circumference inter-orbital index across different population is yet to establish a consistent pattern of gender and ethnic differences.

The normal values of inner and outer canthal distances, canthal index, head circumference and circumference inter-orbital index are important for successful reconstruction of the canthal and head region (Juberg et al., 1975). In this present study, the subjects were divided into 3 age groups, the minimum age being 18 and the maximum 47 for both male and female subjects.

At the minimum value, the head circumference of the females $(52.2 \mathrm{~cm})$ is slightly higher than that of the males $(52.0 \mathrm{~cm})$, the inner canthal distance is the same for both male and female subjects $(3.0 \mathrm{~cm})$, the outer canthal distance of the males $(11.5 \mathrm{~cm})$ is slightly higher than that of the females $(11.2 \mathrm{~cm})$, the canthal index of the males (25.8) is higher than the female value (24.0) and the circumference interorbital index of the males (5.4) is also higher than the females (5.1) at the minimum value.

At the maximum value, the head circumference is higher in females $(62.5 \mathrm{~cm})$ than males $(60.0 \mathrm{~cm})$, the inner canthal distance is higher in males $(5.5 \mathrm{~cm})$ than females $(5.3 \mathrm{~cm})$, the outer canthal distance is slightly higher in males $(14.6 \mathrm{~cm})$ than in females (14.5).

The canthal index of males is 41.6 and is higher than the female value of 37.5 and also the circumference interorbital index of the males (9.9) is higher than the female (9.1) at the maximum value. Also the mean \pm SD of head circumference is significantly higher $(\mathrm{p}<0.05)$ in females $(56.8 \pm 1.9 \mathrm{~cm})$ than males $(56.5 \pm 1.5 \mathrm{~cm})$, the mean \pm SD of inner canthal distance in males $(4.1 \pm 0.4 \mathrm{~cm})$ is significantly higher $(\mathrm{p}<0.05)$ than the females $(3.1 \pm 0.4)$, the mean $\pm \mathrm{SD}$ of outer canthal distance is significantly higher $(\mathrm{p}<0.05)$ in males $(13.1+0.5 \mathrm{~cm})$ than 
females $(12.7+0.6 \mathrm{~cm})$ and also the same for the canthal index and circumference interorbital index where the male value $(31.6 \pm 2.8$ and $7.3 \pm 0.7$ respectively) is significantly higher $(\mathrm{p}<0.05)$ than that of the female $(29.3+2.5$ and $6.8+4.1)$

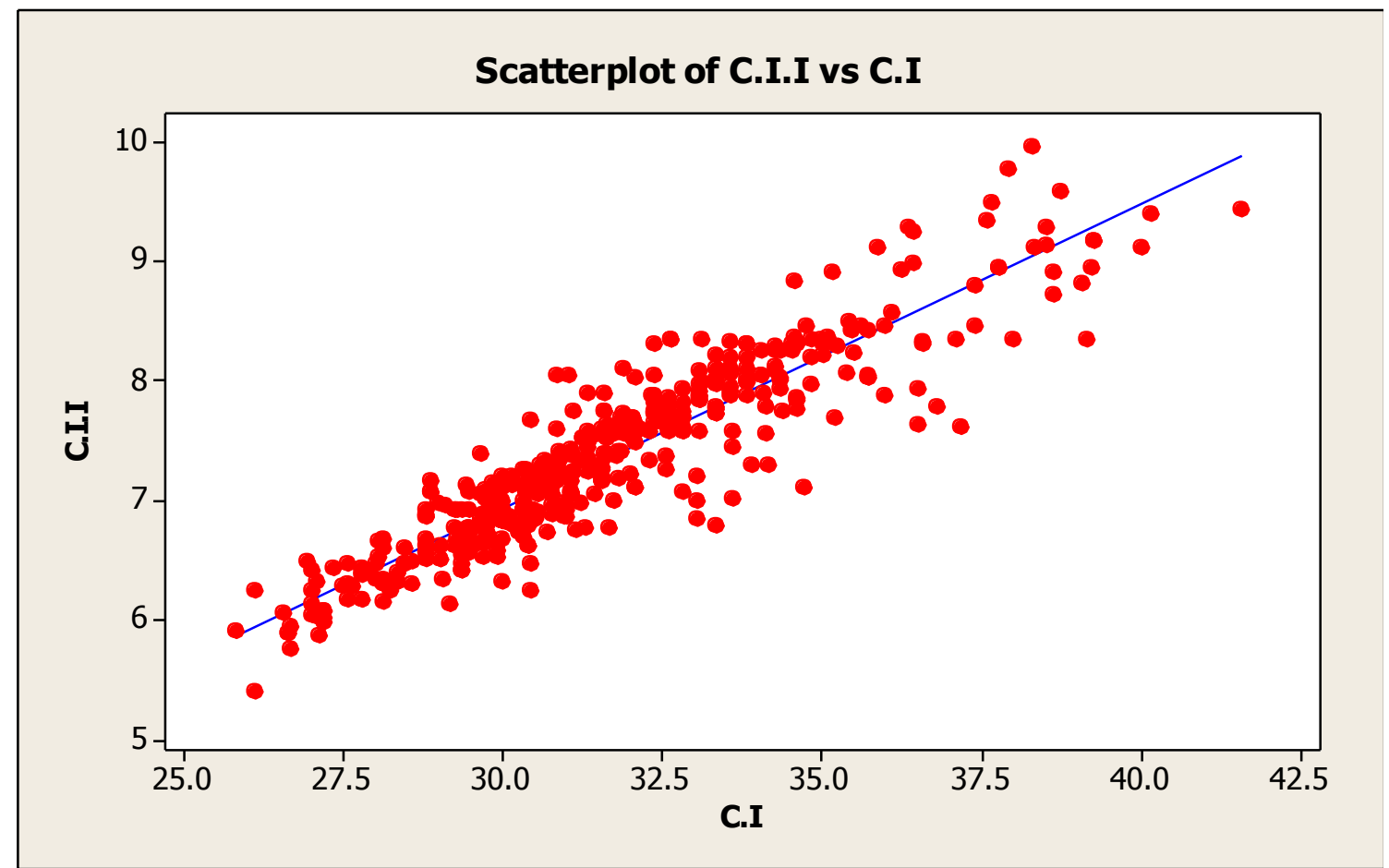

Fig.1. Pearson correlation of C.I.I and C.I for Annang males. R=0.920

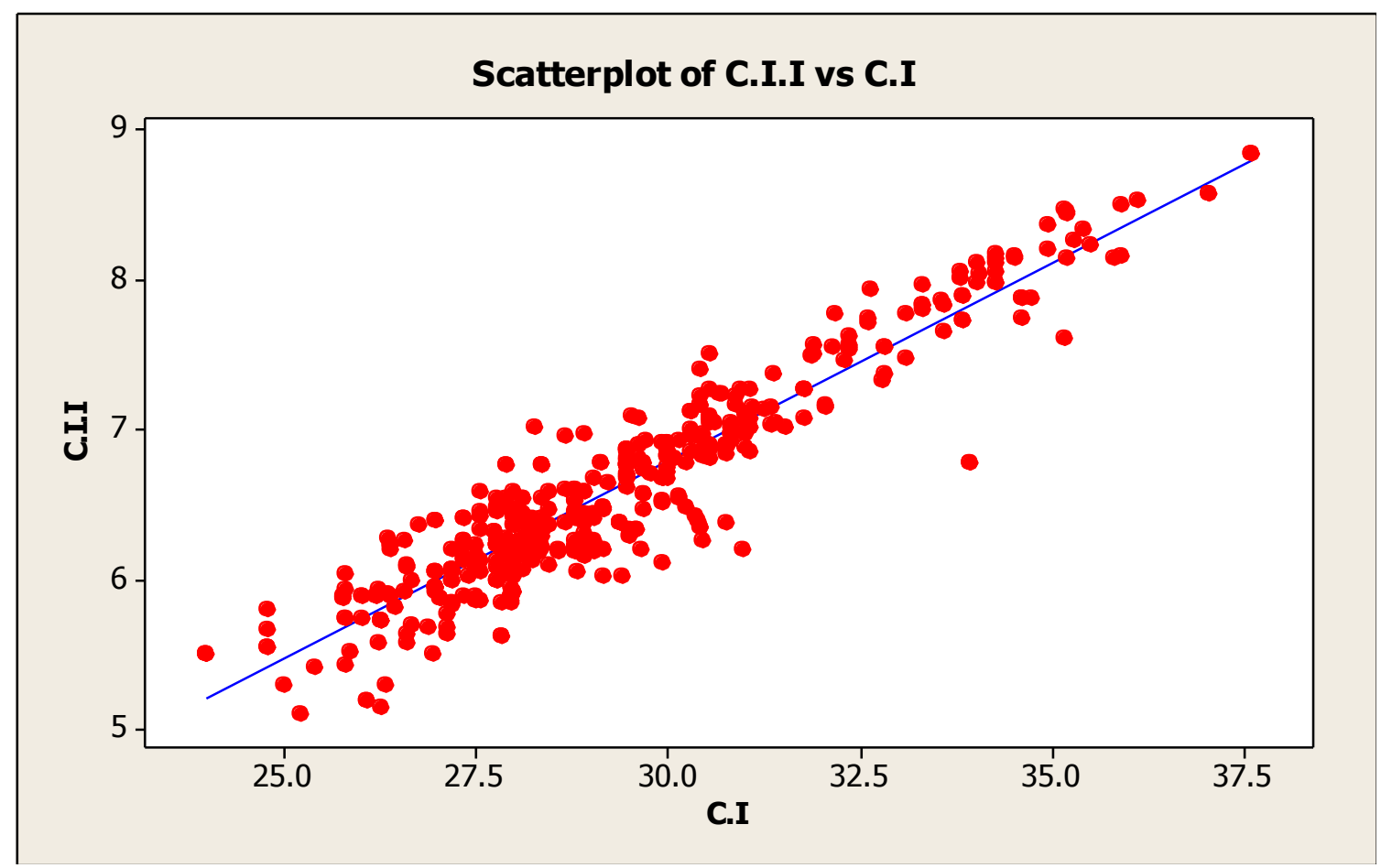

Fig.2. Pearson correlation of C.I.I and C.I for Annang females. R=0.940

The values in this study for the various craniofacial parameters are similar to previous studies. The difference is statistically significant $(\mathrm{p}<0.05)$ thereby establishing the fact that sexual dimorphism exist among the adult 
Annangs which is in agreement with earlier researchers like Anibor et al., (2014) and Oladipo et al., (2008). However, the values obtained for circumference inter-orbital index was lower than the one obtained by Chukwujekwu et al., 2014 on adult Igbos where the males had 10.6 \pm 0.6 and females $10.4 \pm 0.7$ and Oladipo et al.,(2008) on adult Ijaws where the males had $7.8 \pm 2.2$ and females $8.10 \pm 0.6$. Observation in the mean values of this present study showed that the craniofacial parameters in this study were significantly higher in male subjects than in the female subjects $(\mathrm{ICD}=4.1 \pm 0.4 \mathrm{~cm} ; 3.7 \pm 0.4 \mathrm{~cm}, \mathrm{OCD}=13.1 \pm 0.5 \mathrm{~cm} ; 12.7 \pm 0.6 \mathrm{~cm}, \mathrm{C} . \mathrm{I}=31.6 \pm 2.8 ; 29.3 \pm 2.5$ and CI.I $=7.3 \pm 0.7 ; 6.8 \pm 4.1$ at $p<0.05$ ), except in the head circumference where the female subjects had a higher value $(\mathrm{HC}=56.5 \pm 1.5 \mathrm{~cm} ; 56.8 \pm 1.9 \mathrm{~cm}$ at $\mathrm{p}<0.05)$.

\section{Conclusion}

The result of this study showed in all parameters that Annang males had a significantly higher value than the females $(\mathrm{ICD}=4.1 \pm 0.4 \mathrm{~cm} ; 3.7 \pm 0.4 \mathrm{~cm}, \mathrm{OCD}=13.1 \pm 0.5 \mathrm{~cm} ; 12.7 \pm 0.6 \mathrm{~cm}, \mathrm{C} . \mathrm{I}=31.6 \pm 2.8 ; 29.3 \pm 2.5$ and CI.I= $7.3 \pm 0.7 ; 6.8 \pm 4.1$ at $\mathrm{p}<0.05)$ except in head circumference where the females had a slightly higher value $(\mathrm{HC}=$ $56.5 \pm 1.5 \mathrm{~cm} ; 56.8 \pm 1.9 \mathrm{~cm}$ at $\mathrm{p}<0.05)$. The results of this study will help to establish baseline values for head circumference, inner canthal distance, outer canthal distance, canthal index and circumference inter-orbital index for the adult Annangs in Nigeria.

It will also help in understanding the craniofacial growth pattern of males and females of Annang ethnic origin, the normal values of the various craniofacial parameters in this study can be used by clinicians in the evaluation and treatment of congenital or post traumatic deformities of cephalic and facial regions and it will also be used for anthropometric and forensic purposes.

\section{Declarations}

\section{Source of Funding}

This research did not receive any specific grant from funding agencies in the public, commercial, or not-for-profit sectors.

\section{Competing Interests Statement}

The authors declare no competing financial, professional and personal interests.

\section{Ethical Approval}

Ethical approval for this research was given based on institutional guidelines.

\section{Consent to participate}

The consent to participate in this research was sought for and approved by the subjects to be used

\section{Consent for publication}

We declare that we consented for the publication of this research work.

\section{Availability of data and material}

Authors are willing to share data and material according to the relevant needs. 
References

Anibor, E., Ogbo-Omorie, E., Ogadima, P.N. (2014). The Circumference Inter-orbital Index of the Isoko Ethnic Group in Nigeria. The African Journal of Cellular Pathology, 3:1-4.

Anibor, E., Omokaro, E. and Ofere, F. (2014): Variations of the Canthal Index of the Isokos in Delta State. The International Journal of Basic, Applied and Innovative Research, 3(4): 143-146.

Chukwujekwu, I.E., Ezejindu, D.N., Aduwenye, O.I. (2014): Study of Head Circumference Interorbital index between the ages of 19-29 years of Igbo tribes in Otolo, Okofia, Nnewi, Anambra state Nigeria, International Journal of Research, 1(2): 239-244.

Ekanem, J.B. (2002). Clashing cultures: Annang, notwithstanding Christianity: An Etholography (Gods, Humans and Religions). Peter Lang Publishing House: Brussels. ISBN 0-8204-4687-4.

Evereklioglu, C., Doganay, S., Er, H., Tercan, M., Gunduz, A., Balat, A., Cumurcu, T. (2002): Craniofacial anthropometry in a Turkish population. The Cleft Palate-Craniofacial Journal, 39(2): 208-218.

Farkes, L.G., Posnick, J.C., Hreezko, T.M. (1992a): Anthropometric growth study of the head. Cleft Palate Craniofacial Journal, 29(1): 303-308.

Farkes, L.G., Posnick, J.C., Hreezko, T.M., Prons, G.E. (1992b): Growth patterns in orbital region. Cleft Palate Craniofacial Journal, 29(1): 315-318.

Francis, B.Q. (2000): Preoperative evaluation of the Aesthetic patient. Grand Rounds Presentation, University of Texas Medical Branch, Department. of Otolaryngology. The morphologic structure of the open bite in adult Taiwanese.

Jaja, B.N., Fawehinmi, H.B. and Jack, J.T. (2011): Craniofacial anthropometry in a young Nigerian population: the canthal distances. International Journal of Morphology, 29(3): 914-917.

Juberg, R.C., Sholte, F.G., Touchstone, W.J. (1975): Normal values for inter canthal distance of 5-11 years old of American blacks. Acta Paediatrica, 55(3): 431-436.

Oladipo, G.S., Akande, P.A., Osogba, I.G., Yorkum, K.L. (2011): Anthropometric studies of Inner Canthal Distance, Outer Canthal Distance and Canthal Index of Adult Ibibios. Asian Journal of Medical Sciences, 3(1): 14-16.

Oladipo, G.S., Ugboma, A., Oyakhire, M. (2008). The Circumference Interorbital Index OfIjaw and Igbo Ethnic Groups in Nigeria. The Internet Journal of Biological Anthropology, 3(2): 1-5.

Oladipo, G.S., Okoh, P.D. and Hart, J.S. (2010).Anthropometric Study of Ocular Dimensions in Adult Ijaws of Nigeria. Research Journal of Medicine and Medical Sciences, 5(2): 121-124.

Oladipo, G.S., Yorkum, L.K., Okoh, P. (2013): Measurement of Head Circumference, Intercanthal Distances, Canthal Index and Circumference Interorbital Index of Ikwerre School Children in Nigeria. Journal of Natural sciences Research, 3(4): 16-20. 
Osunwoke, E.A., Didia, B.C., Olotu, E.J., Yerikeme, A.H. (2012): A Study on the Normal Values of Inner Canthal, Outer Canthal, Interpupiliary Distance and Head Circumference of 3-21 years Ijaws. American Journal of Scientific and Industrial Research, 3(6): 441-445.

Shah, S., Koirala, S. (2014). Study of Canthal Index in Nepalese Undergraduate medical students of BPKIHS, Nepal: Gender and Ethnic Differences. Journal of Kathmandu Medical College, 3(2): 78-81.

Udoh, E.U. (1983). The History of the Annang People.Calabar Nigeria: Apcon Press Ltd, pp. 182-191.

Umoh, E. (2004). Annang Map with boundaries. Plano TX. USA.

Williams, P.L., Bannister, L.H., Dyson, M., Collin, P. (1995): Gray’s Anatomy, $38^{\text {th }}$ Edition. Edinburgh, London: Churchill Livingstone, pp. 609-612. 